\title{
1 Advancing a farmer decision support tool for agronomic decisions on rainfed and 2 irrigated wheat cropping in Tasmania.
}

3

4 David C. Phelan ${ }^{\mathrm{a} *}$, Matthew T. Harrison ${ }^{\mathrm{b}}$, Greg McLean ${ }^{\mathrm{c}}$, Howard Cox ${ }^{\mathrm{c}}$, Kieth G. Pembleton ${ }^{\mathrm{d}}$, Geoff J. 5 Dean $^{\mathrm{e}}$, David Parsons ${ }^{\mathrm{f}}$, Maria E. do Amaral Richter ${ }^{\mathrm{a}}$, Georgie Pengilley ${ }^{\mathrm{e}}$, Sue J. Hinton ${ }^{\mathrm{e}}$, Caroline L. 6 7

aTasmanian Institute of Agriculture, University of Tasmania, Private Bag 98, Hobart TAS 7001, Australia.

${ }^{\mathrm{b}}$ Tasmanian Institute of Agriculture, PO Box 3523, Burnie TAS 7320, Australia

'Department of Agriculture, Fisheries and Forestry, PO Box 102, Toowoomba QLD 4350, Australia

${ }^{\mathrm{d}}$ University of Southern Queensland, School of Agriculture, PO Box 102, Toowoomba QLD 4350, Australia.

eTasmanian Institute of Agriculture, Mt Pleasant Research Laboratories, PO Box 46, Kings Meadows TAS 7249, Australia.

fDepartment of Agricultural Research for Northern Sweden, Swedish University of Agricultural Sciences, SE-901 83 Umeå, Sweden.

\section{Abstract}

Well-designed agricultural decision support tools (DS) equip farmers with a rapid, easy way to compare multiple scenarios as well as the influence of different management strategies on crop production. One such tool, CropARM (http://www.armonline.com.au) assists users in establishing a framework of risk, with simulations incorporating climate scenarios and management actions, such as fertiliser rates, sowing time, row spacing, and irrigation regimes. When used in conjunction with soil and climate characteristics, biophysical model-based DS tools provide information that complements farmer experience and helps establish a framework for risk management given local climate characteristics. In this study, we used the APSIM model to provide the simulation data necessary to expand CropARM for new management conditions and environments in southern Australia. Prior to this work being undertaken, no CropARM data was available for Tasmania and no sites in CropARM allowed users to compare rainfed and irrigated wheat crops. This study collated data from 27 plots across ten sites in Tasmania, from the period 1981 to 2011, under both rainfed and irrigated conditions. APSIM was parameterised with these field observations and the subsequent scenario simulations were used to 
populate CropARM. Wheat cultivars used in the parameterisation of APSIM include Brennan, Isis,

31 Mackeller, Revenue, Tennant (winter types) and Kellalac (spring type). The validation showed reliable

32 model parameterisation, with an $r^{2}$ value of close to 1, which is considered satisfactory. 670,680

33 simulations were undertaken and incorporated within the CropARM database for wheat cropping

34 systems across Tasmania. With regularly updated climate streams, the free online framework provided

35 by CropARM gives users the ability to assess downside risks associated with several different crop management alternatives, and by simultaneously comparing multiple scenarios, users can select management options that are likely to adhere most closely with their desired management objectives.

Key Words

40

CropARM; APSIM; biophysical modelling; parameterisation.

41

\section{Introduction}

Agricultural decision support (DS) tools equip users with a rapid and cost-effective means of contrasting multiple scenarios to gauge the influence of different management strategies on farm production and profitability (Nelson et al., 2002; Hochman and Carberry 2011; Rose et al., 2016). Such tools provide information that complements farmer experience and establishes a framework for risk management where declining profitability and increasing climatic variability within agriculture increasingly pose complex challenges (Hochman and Carberry 2011; Jakku and Thorburn 2010). Such challenges necessitate the integration of scientific knowledge into decision support tools that can assist primary producers contemplating farm management decisions (Jakku and Thorburn 2010). Agricultural DS tools are typically software applications, commonly based on models describing various biophysical processes in farming systems and the response to varying management practices (Jakku and Thorburn 2010; Rose et al., 2016). Decision support tools designed for assessing crop management often require data regarding climate, soils, farm management and crop genotype (Carberry et al., 2002; Nelson et al., 2002; Hochman et al., 2009). Data is typically collected directly from archived records, such as the national climate and soil databases available in Australia (SILO climate data and ASRIS; 
https://www.longpaddock.qld.gov.au/silo/, http://www.asris.csiro.au/) and is used in biophysical models including the Agricultural Production Systems Simulator (APSIM). APSIM uses a modular framework that allows users to 'plug-and-play' management as well as soil and crop components in a graphical user interface (Holzworth et al., 2006). This feature circumvents the need for model derivation from first principles or programming coding underlying mathematics in low-level programming languages, isolating execution semantics of computer architecture from users and increasing ease of use.

The APSIM model has been used to provide simulation data that underpins DS tools including FARMSCAPE (Carberry et al., 2002), Yield Prophet (Hochman et al., 2009) and Whopper Cropper (Nelson et al., 2002). The Whopper Cropper software tool was developed in consultation with public and private advisors/consultants, partly in response to demand for access to the cropping systems modelling capability of APSIM (Keating et al., 2003). Whopper Cropper provides information on the impact of climate risk on crop yields for crop management alternatives beyond the experience of individual farmers, using historical climate data to obtain seasonal cropping perspectives (Nelson et al., 2002). Recently, Whopper Cropper was transformed into the online set of tools called Agricultural Risk Management, hosted by the Queensland Government (ARM online, see http://www.armonline.com.au/\#/wc. APSIM simulations have been used to provide information for the ARM tools, such as NitrogenARM and CropARM. Each tool has user-defined management options including soil type, water profile capacity at sowing, cultivar and plant density as well as sowing date and nitrogen (N), amongst others. Additionally, CropARM calculates growers' exposure to risk when comparing various management inputs such as applications of $\mathrm{N}$ fertiliser along with resource-based options such as stored soil water. When used in conjunction with soil and climate characteristics, biophysical model-based DS tools provide information that enhances farm manager experience and provides a framework for risk management given prevailing climate characteristics as determined by location, for example early frost incidence or the influence of heat waves during anthesis, that can severely penalise grain yield. 
84 Effects of different management locations and cultivars in CropARM can be displayed alone or in

85 combination with other inputs. Each simulation uses 115 years of climate records and the APSIM model

86 to simulate year-to-year variability in yields along with related information including crop biomass,

87 grain protein, in-crop rainfall, days to harvest, water use efficiency and minimum and maximum in-

88

89 competently simulate crop growth and yield, and water and nitrogen balances across a wide range of environments (Acuna et al., 2015; Keating et al., 2003; McCormick et al., 2015; Robertson and Lilley 2016; Wang et al., 2010). The CropARM outputs use climate records from SILO and the national soil grid provided by the Australian Soil Resource Information Systems (ASRIS) (http://www.asris.csiro.au/). This enables users to make informed decisions about the risk associated with various management conditions whilst taking account of interactions between crop biology with climate (phenology) given similar growing season conditions experienced in the past.

Like all DS tools, CropARM can only include a set number of crops types and management alternatives. Prior to this study, the DS tool only contained data from mainland Australia and excluded data for the southern-most state, Tasmania. Further, agronomic information for mainland sites contains only simulations of rainfed crops. In order to keep pace with growing dairy industry expansion in Tasmania, the Grains Research and Development Corporation (GRDC) recently invested in new research projects to double Tasmanian grain production in the next five years to approximately 160,000 tonnes/annum (Ryan, 2015). With the rollout of new irrigation schemes across the State from a $\$ 220$ million investment (http://www.tasmanianirrigation.com.au), grain is becoming commercially competitive with other high-value crops such as poppies (Ryan, 2015). Such developments mean that farmers in Tasmania may be more inclined to produce cereals and dual-purpose grain crops, which are common in high-rainfall zones of mainland Australia (Harrison et al., 2011). As irrigation infrastructure becomes more available, users will require more agronomic information on irrigation and management option effects on crop yields in different locations of Tasmania. 
The purpose of this study was to parameterise APSIM using observed wheat crop production data from

112 ten sites across Tasmania, and then to incorporate this data into CropARM, since prior to this work no

113 CropARM data were available for the State. Additionally, there were no options for comparing between

114 rainfed and irrigated crop yields within CropARM. Effects of irrigation on crop growth will likely form

115 the basis of decisions made by many Tasmanian farmers regarding whether to sow grain crops or to

116 apply additional water within the growing season. The new CropARM outputs will allow users to

117 contrast relative differences in grain yield caused by management or genotypic differences in multiple

118 regions, allowing insights into of how crop irrigation decisions influence crop phenology and grain

119 yield.

120

121

\section{Materials and Methods}

122

\subsection{Locations}

123

Ten sites were selected as representative of the Tasmanian wheat growing regions. The ten sites span from the north-west coastal region (Forthside, Sassafras) to the Meander Valley (Hagley, Westbury), the northern Midlands (Campbell Town, Cressy, Epping Forest, Longford, Symons Plains), and into the southern Midlands (Cambridge) (Fig. 1). The soil types across the ten sites are diverse due to variations in climate, landscape and geology and include Sodosols, Dermosols and Ferrosols soils (Table 1). There is a significant gradient in average annual rainfall across the ten sites of over $450 \mathrm{~mm}$ per year, from Forthside in the central coast region receiving an annual rainfall of $950 \mathrm{~mm}$ to Campbell Town and Cambridge in the southern region of the state recording $500 \mathrm{~mm}$ annually (Table 1). Mean annual rainfall generally ranges from 500 to $550 \mathrm{~mm}$ in the Southern Midlands, although in some locations the average rainfall is $700 \mathrm{~mm}$ due to the impact of easterly rainfall systems. The Southern Midlands is also prone to severe frosts (Grose et al., 2010). 


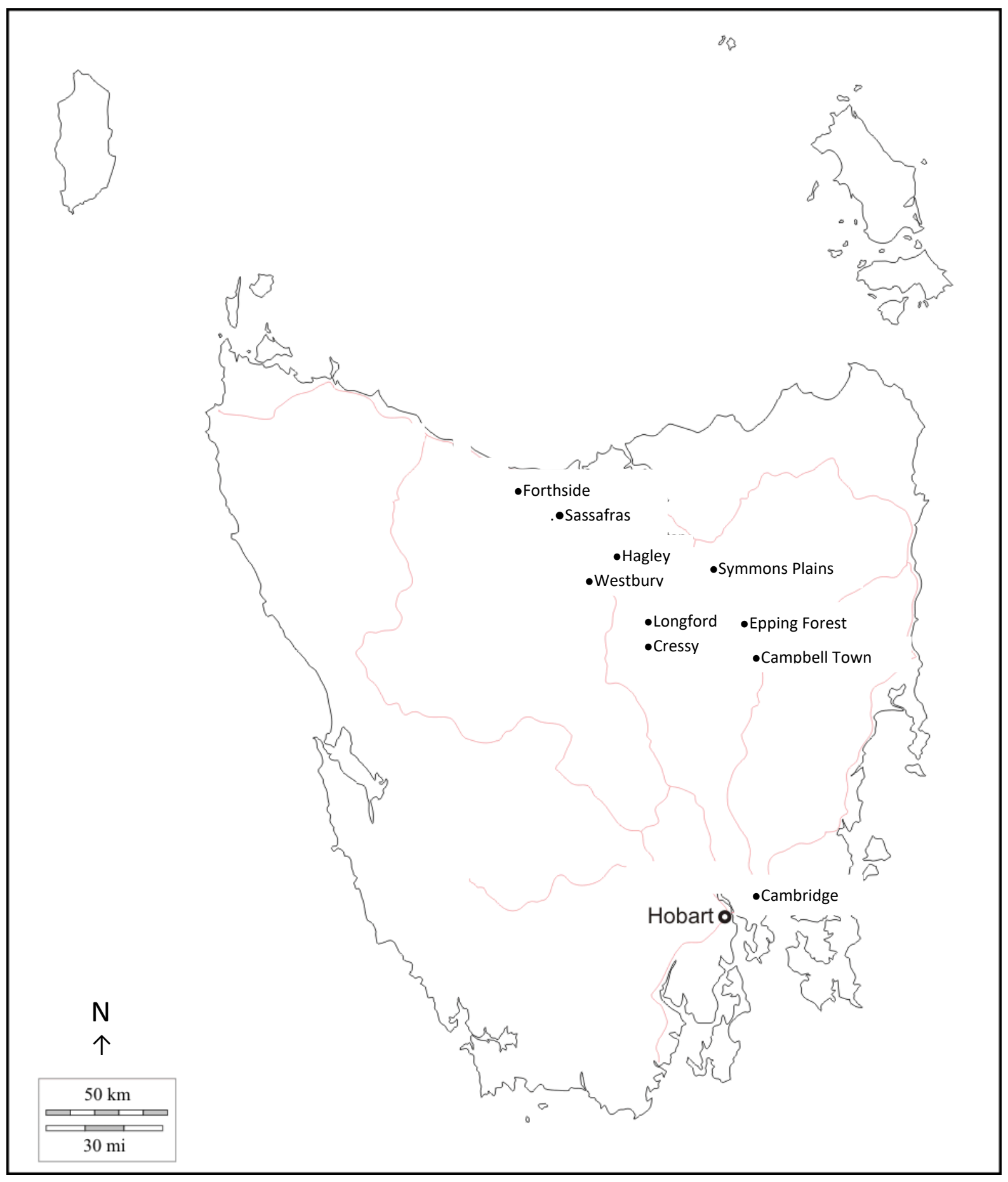

139 Fig. 1. Ten site locations from the north-west to the south-east within Tasmania.

\subsection{Parameterisation}

142 Management and yield data of wheat from 27 field trials at 10 locations for the period of 1981 to 2011

143 were obtained from Acuna et al., (2015). Site details for field wheat trials are shown in Table 1, along

144 with mean annual climate statistics. Parameterised APSIM files (version 7.8) were obtained from Acuña 
et al., (2015). The field trials as reported by Acuna et al., (2015) were sown with winter wheat cultivars

146 (Brennan, Isis, Mackellar, Revenue or Tennant) and a long-season spring wheat (Kellalac), with sowing

147 dates ranging from April to September. Typically, wheat crops in Tasmania are sown in April/May and

148 are harvested in November/December/January (depending on seasonal rainfall and temperature. All

149 cultivars are available in APSIM except for Isis, which was substituted with a new variety adapted to

150 Tasmania (Mackellar_Tas). Nitrogen fertiliser was typically applied at sowing at a rate of $25 \mathrm{~kg}$ N/ha,

151 with a further top-dressed application in early spring of $50 \mathrm{~kg} \mathrm{~N} / \mathrm{ha}$. Approximately half of the field

152 trials received 24 - $60 \mathrm{~mm}$ of irrigation, and two trials received a maximum of $240 \mathrm{~mm}$ of irrigation

153 while the remainder were rainfed (Acuna et al., 2015). Trials were managed to minimise losses due to

154 weed competition and pest damage. Soil parameters were obtained from the APSoil database for

155 Tasmania to represent the prevailing conditions at each site, and long-term climate data was sourced

156 from the Australian Bureau of Meteorology SILO website (http://www.longpaddock.qld.gov.au/silo/

157 Jeffery et al., 2001). Further details of site management details and modelling are given in Acuña et al.,

158 (2015).

159

160

Table 1. Site, region, system, soil type, latitude and longitude, elevation (meters above sea level), mean annual rainfall, and mean annual maximum and minimum temperature (climate values are means for

the period 1981 to 2011).

\begin{tabular}{lllllllll}
\hline Site & Region & System & Soil type & $\begin{array}{l}\text { Lat. }\left({ }^{\circ} \mathrm{S}\right) \\
\text { Long. }\left({ }^{\circ} \mathrm{E}\right)\end{array}$ & Elevation & Rainfall (mm) & \multicolumn{2}{c}{$\begin{array}{c}\text { Annual temp }\left({ }^{\circ} \mathrm{C}\right) \\
\text { Min }\end{array}$} \\
\hline Cambridge & $\mathrm{SE}$ & Irrigated \& rainfed & Sodosol & $42.79^{\circ}, 147.42^{\circ}$ & 45 & 501 & 17.5 & 8.1 \\
Campbell Town & $\mathrm{NM}$ & Rainfed & Dermosol & $41.92^{\circ}, 147.49^{\circ}$ & 209 & 499 & 17.6 & 5.6 \\
Cressy & $\mathrm{NM}$ & Irrigated \& rainfed & Sodosol & $41.68^{\circ}, 147.08^{\circ}$ & 149 & 628 & 17.2 & 5.1 \\
Epping forest & $\mathrm{NM}$ & Rainfed & Sodosol & $41.76^{\circ}, 147.35^{\circ}$ & 195 & 628 & 17.2 & 5.1 \\
Hagley & $\mathrm{MV}$ & Rainfed & Dermosol & $41.52^{\circ}, 146.90^{\circ}$ & 149 & 833 & 16.9 & 4.6 \\
Forthside & $\mathrm{NM}$ & Irrigated & Ferrosol & $41.22^{\circ}, 146.27^{\circ}$ & 142 & 965 & 16.1 & 7.4 \\
Longford & $\mathrm{NM}$ & Irrigated & Sodosol & $41.59^{\circ}, 147.12^{\circ}$ & 159 & 628 & 17.2 & 5.1 \\
Sassafras & $\mathrm{NW}$ & Rainfed & Ferrosol & $41.28^{\circ}, 146.49^{\circ}$ & 136 & 777 & 16.9 & 8.2 \\
Symmons Plains & $\mathrm{NM}$ & Rainfed & Sodosol & $41.64^{\circ}, 147.25^{\circ}$ & 159 & 628 & 17.2 & 5.1 \\
Westbury & $\mathrm{MV}$ & Rainfed & Dermosol & $41.52^{\circ}, 146.83^{\circ}$ & 169 & 833 & 16.9 & 4.6 \\
\hline
\end{tabular}

Abbreviations: SE, south-east; NM, northern Midlands; MV, Meander Valley. Soil type, Isbell, (1996). 
We undertook simulations for wheat in Tasmania using several starting soil conditions and management options for the ten sites using the APSIM files described above. Each combination of site by management in Table 2 and 3 defines an individual simulation. The simulations were run on a daily time step from 1901 to 2015 with daily climate variables using the historical climate data available from the Australian Bureau of Meteorology SILO website (http://www.longpaddock.qld.gov.au/silo/ Jeffery et al., 2001), resulting in approximately 200,000 simulations.

Table 2. Management factors and associated number of levels within the APSIM factorial simulations (Zadoks et al., 1974)

\begin{tabular}{ll}
\hline Factor & Levels \\
\hline Sowing date & 15 April, 15 May, 15 June, 15 July \\
Seeding rate (plants/m²) & $60,80,110,150,200$ and 250 \\
Row spacing & $1(250 \mathrm{~mm})$ \\
Cultivar & Mackellar_Tas, Revenue, Tennant \\
Initial stored soil water & Soil profile 25\%, 50\% or 75\% full \\
Initial soil N (kg N/ha) & 10,25 and 50 \\
Sowing N applied (kg N/ha) & 0,50 and 100 \\
Top dressing N (kg N/ha) & 60 (kg/ha) applied once, twice or thrice (GS 31, 39, 46) \\
System & Rainfed and irrigated \\
Irrigation regime & Light - Zadoks stage $>10$ and $<71$, soil water deficit (SWD) $>70$ \\
& Light at flowering - Zadoks stage $>62$ and $<68$, SWD $>70$ \\
& Heavy at flowering - Zadoks stage $>62$ and $<68$, SWD $>10$ \\
& Heavy throughout growing season - Zadoks stage $>10$ and $<71$, SWD $>10$
\end{tabular}

A surface residue of wheat biomass of $100 \mathrm{~kg} / \mathrm{ha}$ was initiated in the model, and water, nutrient and surface organic matter levels were reset annually post-harvest (February 1) (Table 2). Table 3 shows the soil type and subsequent soil description and depth, and plant available water capacity (PAWC) for each site, with each row representing an individual simulation within APSIM in combination with Table 2.

Table 3. Site, soil type, description and depth (mm), and plant available water content (PAWC) within the APSIM factorial simulations.

\begin{tabular}{|c|c|c|c|c|}
\hline Site & Soil Type & Soil description & Depth (mm) & Wheat PAWC (mm) \\
\hline
\end{tabular}




\begin{tabular}{|c|c|c|c|c|}
\hline Cambridge & Sodosol & Loam & 1500 & 148 \\
\hline Campbell Town & Dermosol & Fine sandy loam & 1500 & 217 \\
\hline \multirow[t]{3}{*}{ Cressy } & Sodosol & Fine sandy loam & 1500 & 217 \\
\hline & & Clay loam & 800 & 96 \\
\hline & & Loam & 1400 & 221 \\
\hline \multirow[t]{3}{*}{ Epping Forest } & Sodosol & Fine sandy loam & 1500 & 217 \\
\hline & & Clay loam & 800 & 96 \\
\hline & & Loam & 1400 & 221 \\
\hline \multirow[t]{3}{*}{ Hagley } & Demosol & Fine sandy loam & 1500 & 217 \\
\hline & & Clay loam & 800 & 96 \\
\hline & & Loam & 1400 & 221 \\
\hline Forthside & Ferrosol & Red Ferrosol & 1200 & 92 \\
\hline \multirow[t]{2}{*}{ Longford } & Sodosol & Fine sandy loam & 1500 & 217 \\
\hline & & Loam & 1400 & 221 \\
\hline \multirow[t]{2}{*}{ Sassafras } & Ferrosol & Red Ferrosol & 1200 & 92 \\
\hline & & Sandy loam & 1200 & 143 \\
\hline \multirow[t]{3}{*}{ Symmons Plains } & Sodosol & Fine sandy loam & 1500 & 217 \\
\hline & & Clay loam & 800 & 96 \\
\hline & & Loam & 1400 & 221 \\
\hline \multirow[t]{3}{*}{ Westbury } & Dermosol & Clay loam & 800 & 96 \\
\hline & & Loam & 1400 & 221 \\
\hline & & Medium Clay & 1100 & 206 \\
\hline
\end{tabular}

184

\subsection{Statistical analyses}

186 Model performance was evaluated using a range of model evaluation statistics based on the work of

187 Tedeschi, (2006). These included the coefficient of determination $\left(r^{2}\right.$, a measure of closeness between

188 simulated and measured values, ideal $=1)$, Pearson's correlation coefficient $(r$, describes the linear

189 relationship between simulated and measured values, ideal $=1$ ), mean bias (difference between

190 measured and simulated means, ideal $=0$ ), mean prediction error (MPE, model efficiency as a

191 percentage of the mean, ideal $=<5 \%$ ), modelling efficiency $(\mathrm{MEF}$, level of variation explained by

192 simulated values, ideal $=1)$, variance ratio $(v$, ratio of variance in measured to simulated values, ideal

193 = 1) (Cullen, 2008; Pembleton et al., 2013). 
The parameterised outputs from APSIM are compared with the observed field data from the ten sites in Fig. 3. Visual inspection indicates that the model adequately simulated the measured observed data in terms of total grain yield. Fig. 3 demonstrates reliable model parameterisation, with simulated grain yields that were close to observed values from the ten sites. The model evaluation statistics were close to ideal. A variance ratio of less than unity indicates that a greater level of variation existed in the simulated data compared with the observed data, and this was likely because simulations included multiple years of climatic data (whereas measurements were conducted over only one season). Overall, the evaluation statistics indicate that the model adequately simulated wheat grain yields under rainfed and irrigated conditions with an acceptable degree of confidence.

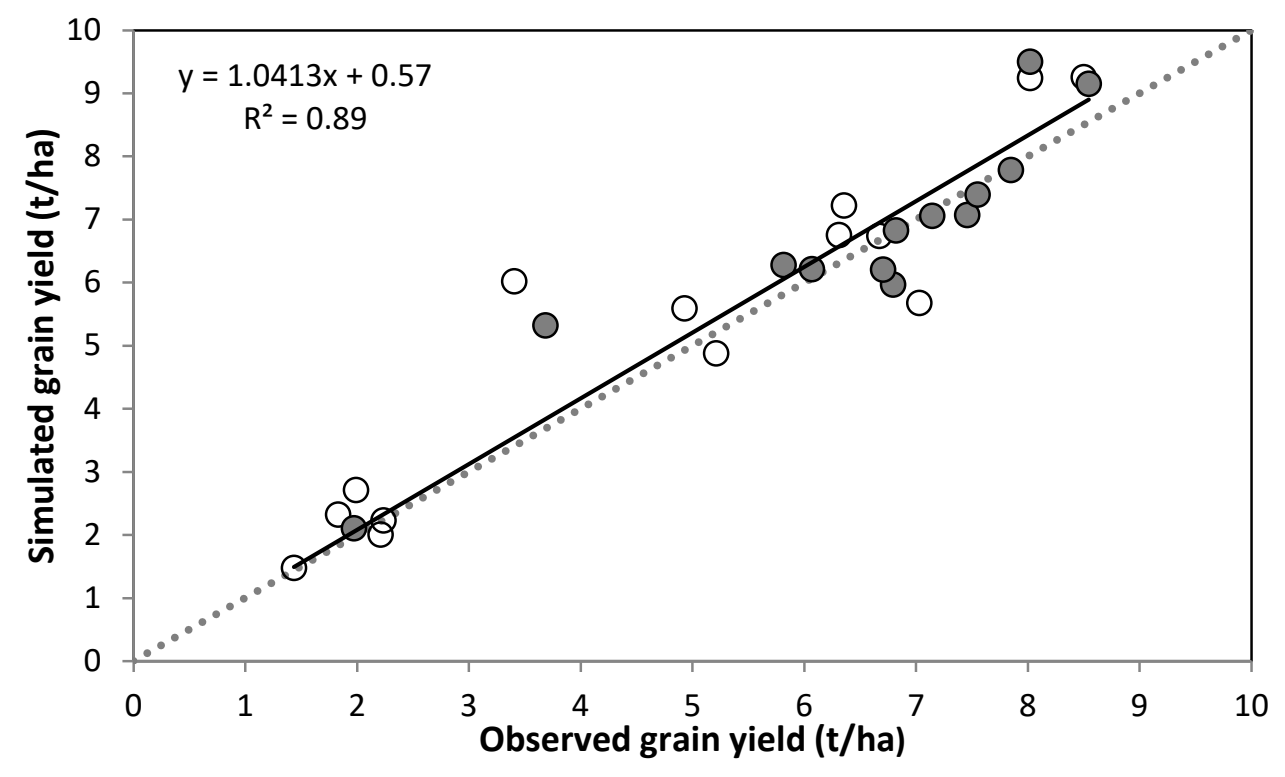

Fig. 3. Simulated and observed total wheat grain yields (t/ha) for the ten sites under rainfed (open circle) and irrigated (closed circle) conditions. The dashed line is 1:1.

\subsection{APSIM validation}

Validation is an important step in verifying the model performance involving a comparison between field observations and simulation outputs (Ahmed et al., 2016). Field wheat data from the sites of Cressy, Symmons Plains, Epping Forest and Burnie were collated for the growing seasons of 2005 to 2010, from various wheat cultivars under rainfed conditions. The performance of APSIM was compared with the observed field data obtained during this period, using data that were not used in the parameterisation 
217 to observed values for the four sites. Similar to the model parameterisation, the model evaluation 218 statistics were close to ideal, indicating that the model adequately simulated wheat grain yields under 219 rainfed conditions with an acceptable degree of confidence (Table 4).

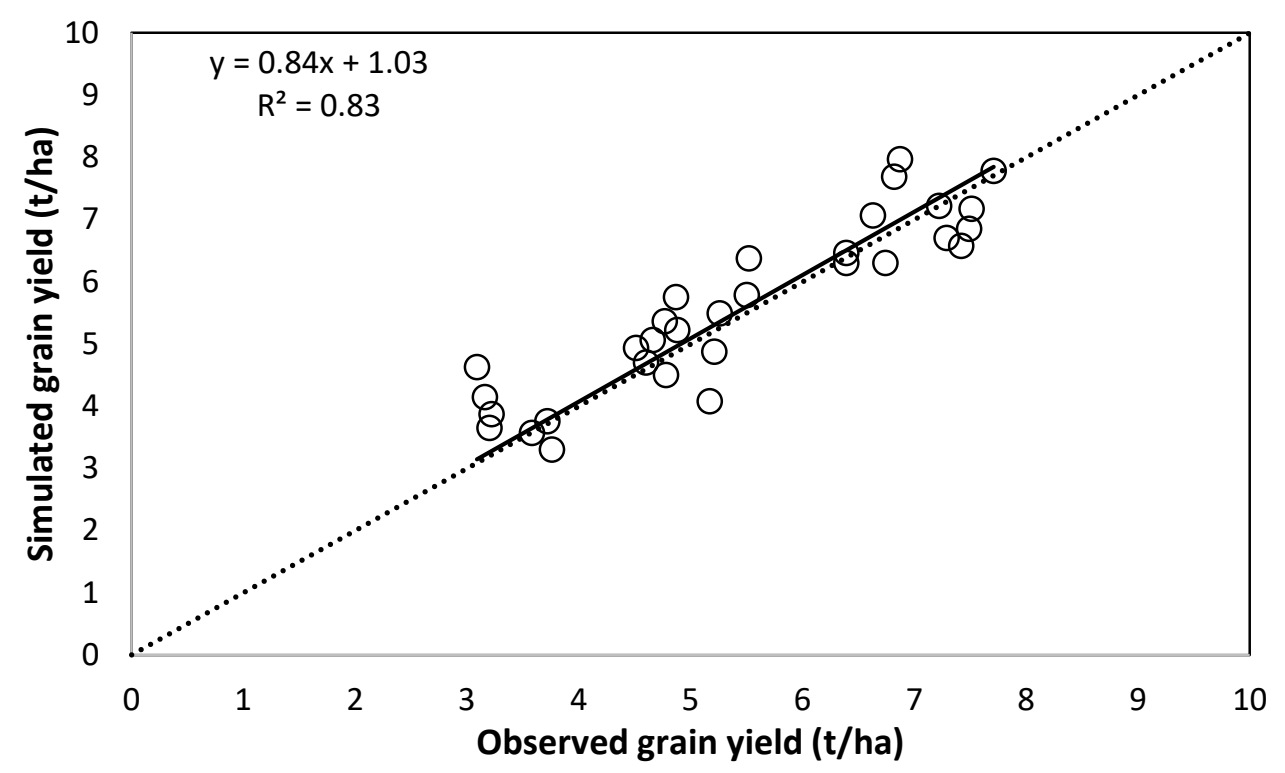

221 Fig. 4. Simulated and observed total wheat grain yields (t/ha) for the four sites under rainfed conditions.

222 The dashed line is 1:1.

223

224 Table 4. Model validation statistics for the observed and simulated mean total grain yield ( $\mathrm{kg} / \mathrm{ha}$ ) across 225 the ten sites. Abbreviations: $r^{2}=$ coefficient of determination; MPE $=$ mean prediction error; $\mathrm{MEF}=$ 226 modelling efficiency; $v$ = variance ratio; $\mathrm{Cb}=$ bias correction factor (Tedeschi, 2006).

\begin{tabular}{lr}
\hline Evaluation statistics & Grain yield (t/ha) \\
\hline Mean (Actual) & 5.42 \\
Mean (Simulated) & 5.58 \\
Std. Dev (Actual) & 1.49 \\
Std. Dev (Simulated) & 1.37 \\
Evaluation statistics & \\
$r^{2}$ & Value \\
MPE & 0.83 \\
MEF & $11 \%$ \\
$v$ & 0.82 \\
$\mathrm{Cb}$ & 1.09 \\
\hline
\end{tabular}


229 CropARM outputs allow users to contrast relative differences in grain yield caused by management or 230 genotypic differences in multiple regions as well how different decisions on crop irrigation may 231 influence crop phenology and grain yield. The first step users must complete is site selection (Fig 5).
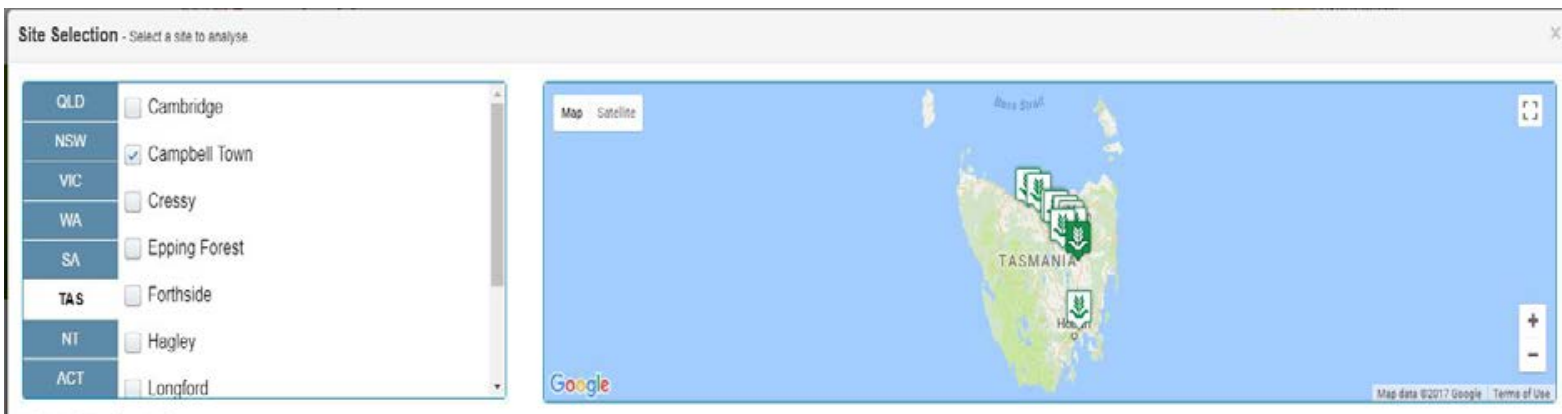

I Sonctos smos. Camsool Toun

233 Fig. 5. CropARM users must first select a site from a given state. In this example, the site of Campbell

Town is chosen.

Following the site selection the next step is selecting the scenario options to analyse as illustrated for

237 Campbell Town in Fig 6. In this case, the site and management options from Table 2 and 3 are shown.

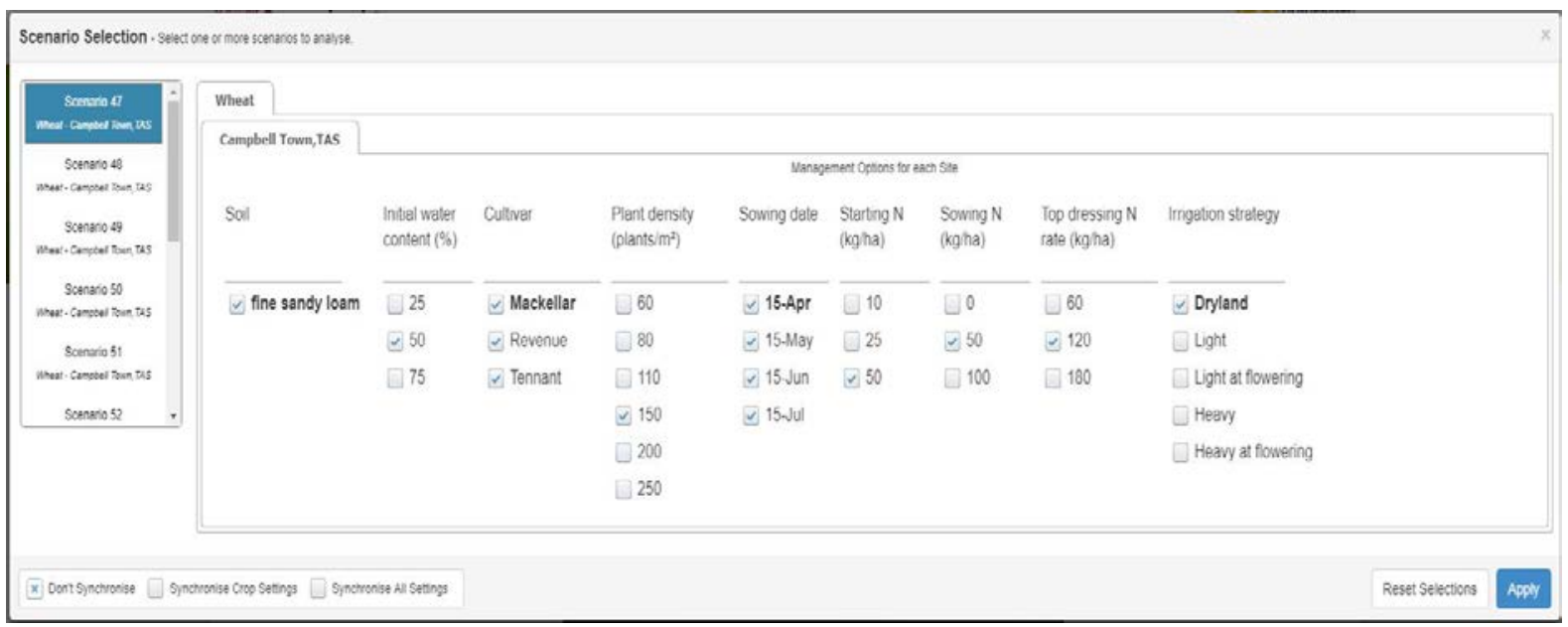

Fig. 6. The CropARM scenario options available for the site of Campbell Town, illustrating the site and management options from Table 2 and 3.

\subsection{Sowing date and irrigation outputs}


243 Methods that allow CropARM users to contrast outputs, for example different sowing dates, cultivars, 244 and $\mathrm{N}$ fertiliser applications during the growing season are shown in Figs. 7 and 8 for Campbell Town.

245 These figures demonstrate how crop management influences the biophysical factors governing yield, such as irrigation and water use efficiency (WUE). Fig. 7a shows rainfed simulations for the four sowing dates (April, May, June, and July), with three wheat cultivars of Mackellar_Tas (representing Mackellar parameterised to Tasmania), Revenue, and Tennant. The soil type is a fine sandy loam and the initial soil water content was $50 \%$, a sowing density of 150 plants $/ \mathrm{m}^{2}$, starting $\mathrm{N}$ of $50 \mathrm{~kg} / \mathrm{ha}$, a sowing $\mathrm{N}$ of $50 \mathrm{~kg} / \mathrm{ha}$ and top dressing $\mathrm{N}$ application rate of $120 \mathrm{~kg} \mathrm{~N} / \mathrm{ha}$. The simulated results show that the timing of sowing is having a significant effect on the median and variability in grain yield, where under rainfed conditions sowing earlier, (April or May) grain yields are both greater and less variable in contrast to sowing in June and particularly July. On the other hand, there are only slight differences in the variation of the grain yields between the three cultivars (Fig. 7a).

Fig. $7 b$ shows the simulation results for the cultivar Mackellar_Tas, with two levels of irrigation; lightly irrigated at flowering and heavy irrigation throughout the growing season along with the rainfed simulations, under the four sowing dates of April, May, June, and July. Both light irrigation at flowering or heavy irrigation throughout the growing season increases yields and reduces the variability in the expected yields in contrast to the rainfed simulations. Application of irrigation water also reduces the variance in yields between the monthly sowing times in contrast to the rainfed simulations, particularly when the crop is heavily irrigated through the growing season (Fig. 7b). Heavy irrigation for late sowing (July) may reduce the yield loss experienced with later sowing of rainfed crops at Campbell Town. 


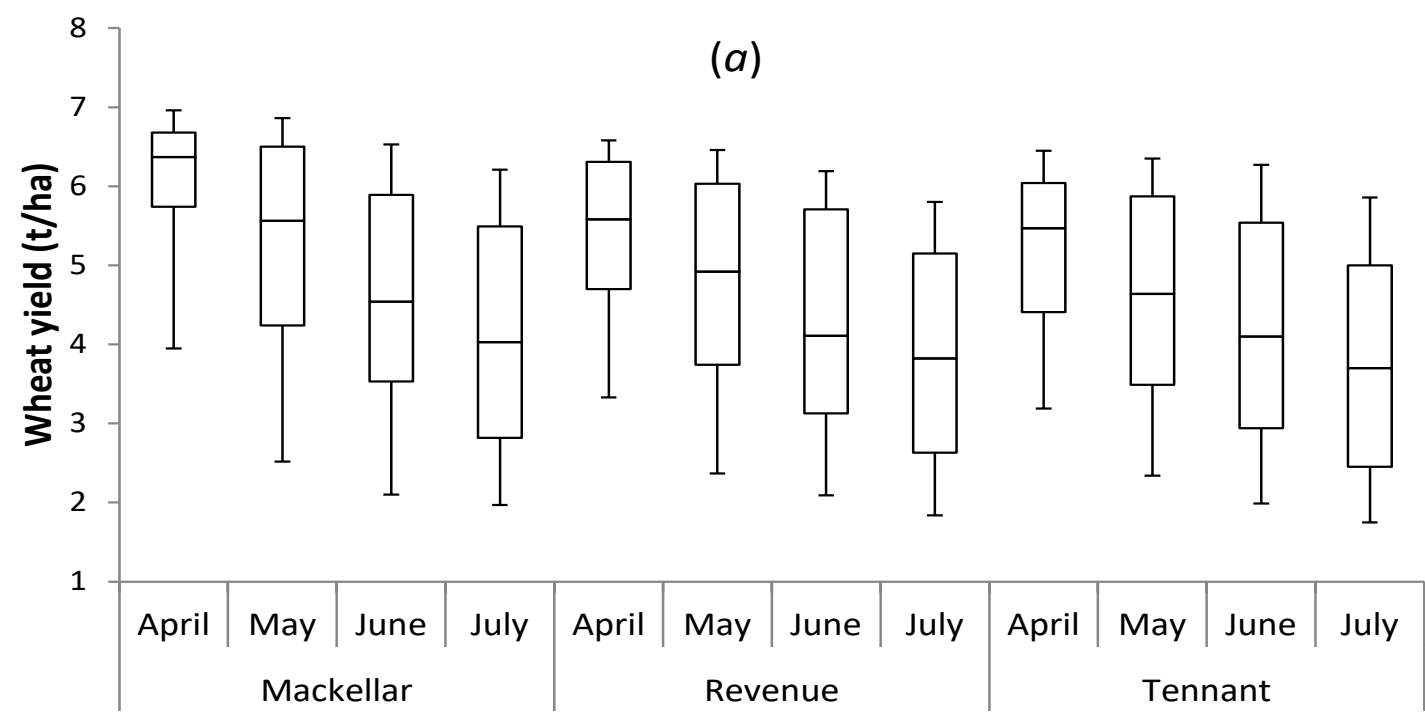

265

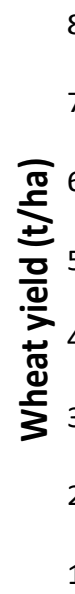

266

Fig. 7. Simulated wheat grain yield (t/ha) for sowing dates of April, May, June, and July, for the cultivars Mackellar_Tas, Revenue, and Tennant under rainfed conditions (a). Simulated grain yield (t/ha) for sowing dates of April, May, June, and July, for the cultivar Mackellar under rainfed, and irrigation light at flowering and heavily irrigated throughout the growing season $(b)$ box plots $\left(5^{\text {th }}, 25^{\text {th }}\right.$, $50^{\text {th }}, 75^{\text {th }}$ and $95^{\text {th }}$ percentile) for the site of Campbell Town.

For Campbell Town with two levels of irrigation the amount of applied irrigation water steadily increases from sowing in April through to July. The irrigation amount applied under the light at flowering scenario increases from $33 \mathrm{~mm} / \mathrm{ha}$ when sown in April through to $61 \mathrm{~mm} /$ ha when sown in July, however grain yields decline with a later sowing date (Fig. $7 b$ ), despite an increase in irrigation water. Similarly, under the heavy irrigation scenario, the irrigation amount applied also increases from 
$217 \mathrm{~mm} / \mathrm{ha}$ when sown in April to $273 \mathrm{~mm} / \mathrm{ha}$ when sown in July, along with an increase in grain yield from sowing in April through to July (Fig. $7 b$ ). The management effect of various irrigation regimes is also reflected in the water use efficiency of each scenario (Fig. 8). The greatest water use efficiency was achieved under the light irrigation at flowering scenario in comparison to the rainfed (excluding April where there was no discernible difference), and particularly the heavy irrigation through the growing season scenario. Acuna et al., (2015) indicated that the timing of sowing annual crops commonly has only a small effect on total crop water use but can have a marked effect on water use efficiency, adding that the highest water use efficiencies are consistently achieved when the crop is sown at the optimum time (too early risks early seed death due to disease or water limitation, as well as frost during flowering, and sowing too late has multiple other risks, as described below). Irrigation at flowering is generally used in reproductive organs rather than leaves, which also increases grain WUE. Fig. $7 b$ shows that the optimum yields are being achieved when the crop is sown in April for both the rainfed and lightly irrigated at flowering scenarios, accordingly the highest WUE's are also being achieved with an April sowing. Under the rainfed scenario, the WUE declines by $18 \%$ from a median of $16.5 \mathrm{~kg} / \mathrm{mm}$ in April to a median of $13.5 \mathrm{~kg} / \mathrm{mm}$ in both June and July. Similarly, under the light irrigation at flowering scenario, the largest WUE is achieved when sowing in April (median $16.5 \mathrm{~kg} / \mathrm{mm}$ ) declining by $8 \%$ to June (median $15.1 \mathrm{~kg} / \mathrm{mm}$ ). April sowing also achieves the highest WUE with respect to heavy irrigation however, the WUE is commonly much lower in comparison to both the rainfed and light irrigation at flowering scenarios (Fig. 8). For Campbell Town, late sowing reduces WUE. This occurs for a number of reasons, including, sowing into colder soil delays crop establishment and early vigour, and increasing the proportion of crop evapotranspiration lost as soil evaporation as well as a higher likelihood of heat stress around anthesis and during grain development (Lisson and Cotching, 2011). Sowing too late increases the likelihood of heat stress pre- and post-anthesis, as can be represented by the mean maximum temperature for this period in CropARM. The mean maximum temperature in the four week period surrounding flowering increased from $18^{\circ} \mathrm{C}$ when sown in April to $21^{\circ} \mathrm{C}$ when sown in July (Fig. 9). 


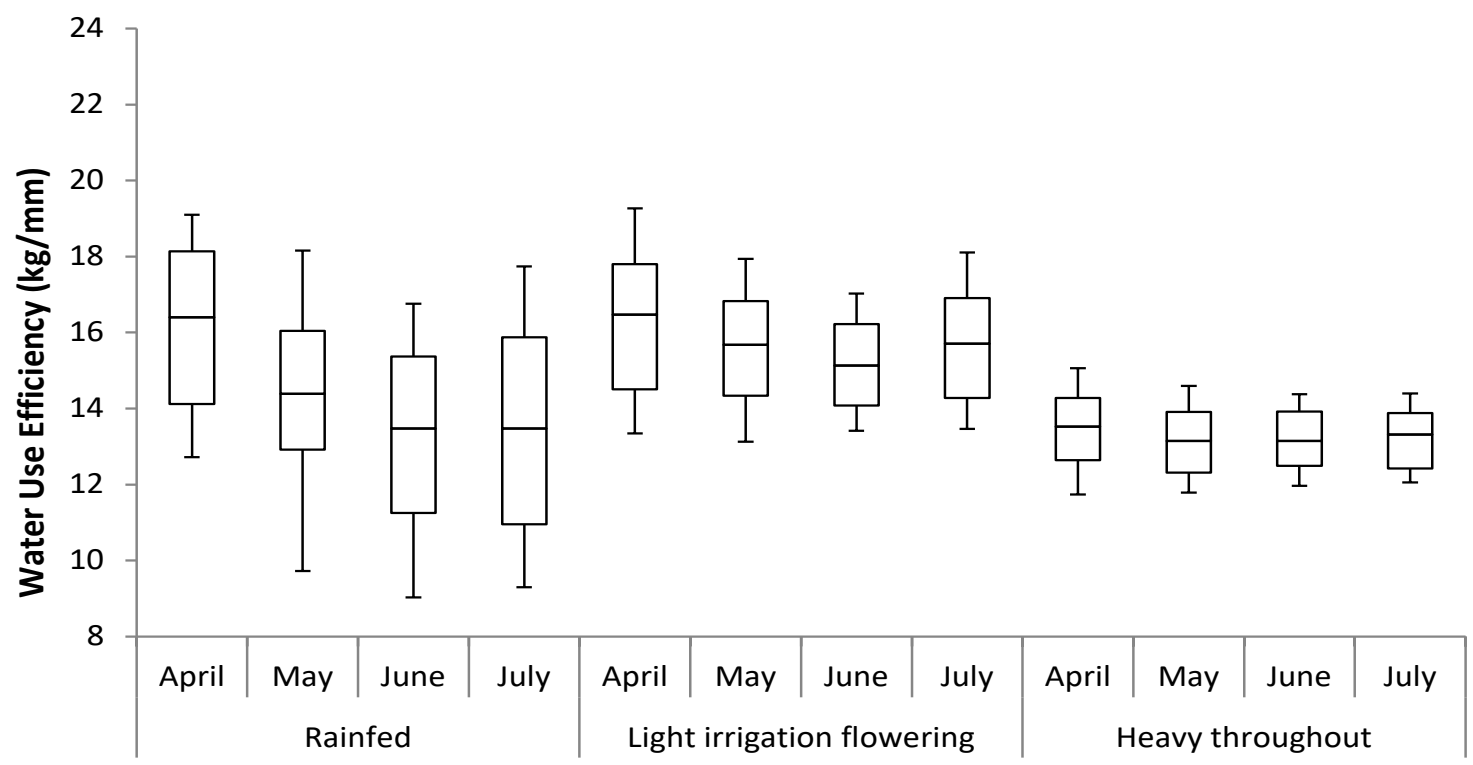

Fig. 8. Simulated water use efficiency (kg grain/[mm rain + irrigation]) of Mackellar_Tas for sowing

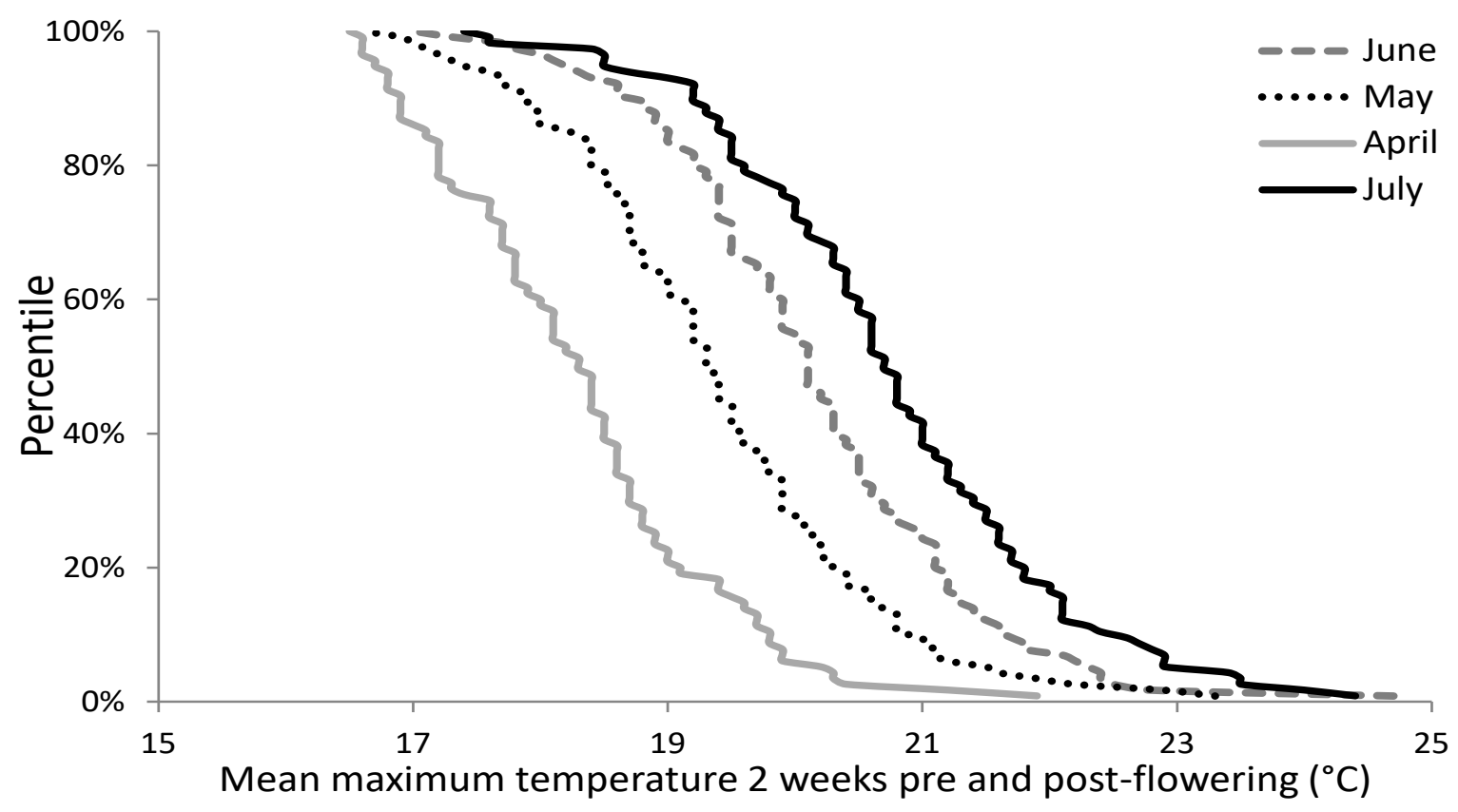

310 Fig. 9. Probability of exceedance mean maximum temperature two weeks pre and post anthesis. The

311 results are for the sowing dates of April, May, June, and July, using Mackellar_Tas cultivar for the site 312 of Campbell Town. 


\subsection{Mineral $N$ at harvest and grain protein outputs}

The effects of the irrigation scenarios at Symmons Plains on grain yield, mineral $\mathrm{N}$ at harvest and grain protein percentage are shown in Fig. 10. This figure shows the cultivar Revenue sown in May, on a clay soil with initial soil water content of $50 \%$, a sowing density of 200 plants $/ \mathrm{m}^{2}$, initial mineral $\mathrm{N}$ of 50 $\mathrm{kg} / \mathrm{ha}$ and a top dressing $\mathrm{N}$ application rate of $120 \mathrm{~kg} \mathrm{~N} / \mathrm{ha}$ under the rainfed, light irrigation at flowering and heavy irrigation scenarios. Two contrasting sowing $\mathrm{N}$ rate scenarios are presented $(0$ and $100 \mathrm{~kg}$ $\mathrm{N} / \mathrm{ha}$ ), in each scenario, the application of $100 \mathrm{~kg} \mathrm{~N} / \mathrm{ha}$ returns higher grain yields although the variability increases with the rainfed and light irrigation at flowering scenarios (Fig 10a). The mean yields of each scenario with the application of $100 \mathrm{~kg} \mathrm{~N} / \mathrm{ha}$ is $4.7 \mathrm{t} / \mathrm{ha}$ (rainfed), $6.1 \mathrm{t} / \mathrm{ha}$ (light irrigation at flowering) and $7.9 \mathrm{t} /$ ha (heavy irrigation). Mineral $\mathrm{N}$ at harvest is a measure of the remaining soil $\mathrm{N}$ post-harvest (Fig 10b). The mineral $\mathrm{N}$ levels at harvest with $100 \mathrm{~kg} \mathrm{~N} / \mathrm{ha}$ applied at sowing, for the rainfed scenario was $42 \mathrm{~kg} \mathrm{~N} / \mathrm{ha}$, light irrigation at flowering $30 \mathrm{~kg} \mathrm{~N} / \mathrm{ha}$ and heavy irrigation $24 \mathrm{~kg}$ $\mathrm{N} /$ ha respectively (Fig. 10b). In the rainfed case, there are many years when the total $\mathrm{N}$ supply is exceeding crop demand due to high residual $\mathrm{N}$ at harvest, in contrast to both the light irrigation at flowering and heavy irrigation scenarios. Lower residual $\mathrm{N}$ at harvest indicates that the rate of $\mathrm{N}$ uptake with irrigated scenarios are higher, reflecting that available soil water in this case, is the principle factor in biomass production and $\mathrm{N}$ uptake rates. If the $\mathrm{N}$ supply for the crop remains relatively constant over the growing season, an increase in yield generally will result in a decrease in protein percentage content due to the dilution of $\mathrm{N}$ by larger biomass production (Harrison et al., 2011). This effect is illustrated in Fig. 11c, where a larger grain protein percentage is observed with the rainfed scenarios with $100 \mathrm{~kg}$ $\mathrm{N} /$ ha fertiliser, which have a grain protein of $15.3 \%$ (low grain yield), in contrast to the irrigated scenarios with grain protein percentages of $14.2 \%$ (light irrigation at flowering ) and $11.8 \%$ (heavy irrigation, higher grain yield). A similar trend is also evident with the scenarios of zero $\mathrm{N}$ applied, where grain protein percentage decreases with increased irrigation applications. Physiological and economic effects of $\mathrm{N}$ can also be examined on the ARM Online site via NitrogenARM, although this facility does not include the Tasmanian sites developed here. 


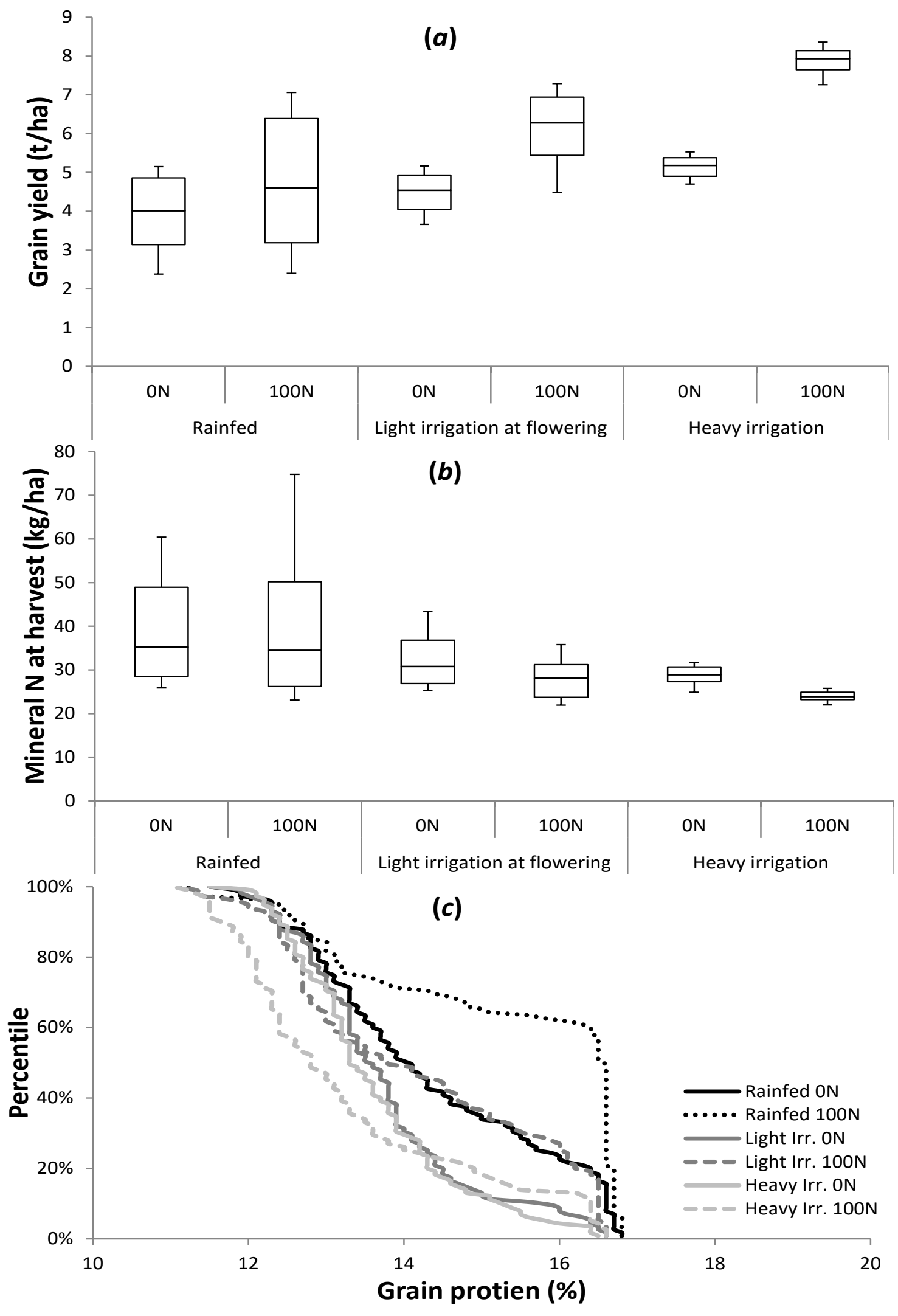

Fig. 10. Simulated wheat grain yield (t/ha) (a) mineral $N$ at harvest $(\mathrm{kg} / \mathrm{ha})(b)$ box plots $\left(5^{\text {th }}, 25^{\text {th }}, 50^{\text {th }}\right.$, $34375^{\text {th }}$ and $95^{\text {th }}$ percentile) and grain protein (\%), probability of exceedance (c) May sowing, Revenue 
cultivar, clay soil, rainfed, light irrigation at flowering and heavy irrigation for the site of Symmons Plains.

\subsection{Gross margin and ENSO effects}

For the site of Sassafras, after an initial analysis of grain yield, two further demonstrations of CropARM capability are shown here, a gross margin analysis and a medium term forecast using the Southern Oscillation Index (SOI) (Ropelewski et al., 1987). This figure shows the cultivar Tennant sown in June, on a red Ferrosol. The initial soil water content of $25 \%$, with a sowing density of 250 plants $/ \mathrm{m}^{2}$, initial mineral $\mathrm{N}$ of $10 \mathrm{~kg} / \mathrm{ha}$, sowing $\mathrm{N}$ of $100 \mathrm{~kg} \mathrm{~N} / \mathrm{ha}$ and a top dressing $\mathrm{N}$ application rate of $120 \mathrm{~kg} \mathrm{~N} / \mathrm{ha}$ (Fig. 11a,b). The rainfed scenario and three irrigation scenarios were selected, light at flowering, heavy, and heavy at flowering. The simulated grain yield results (Fig. 11a) show that larger grain yields were achieved with the heavy irrigation throughout and heavy irrigation at flowering scenarios in contrast to the rainfed and light irrigation at flowering scenarios. In applying heavy irrigation the grain yields range from 5 to 20\% greater than the other simulated scenarios (Fig. 11a). The gross margin analysis however, indicates that the highest crop margins are achieved with the heavy irrigation at flowering scenario, while the gross margins for the rainfed, light irrigation at flowering and heavy irrigation are similar, the variability of gross margins for heavy irrigation is reduced in contrast to the rainfed and light irrigation at flowering scenarios (Fig. 11b). A caveat with gross margins is that results heavily depend on input values, so users are urged to explore the full range of outcomes with diverse variation in input values.
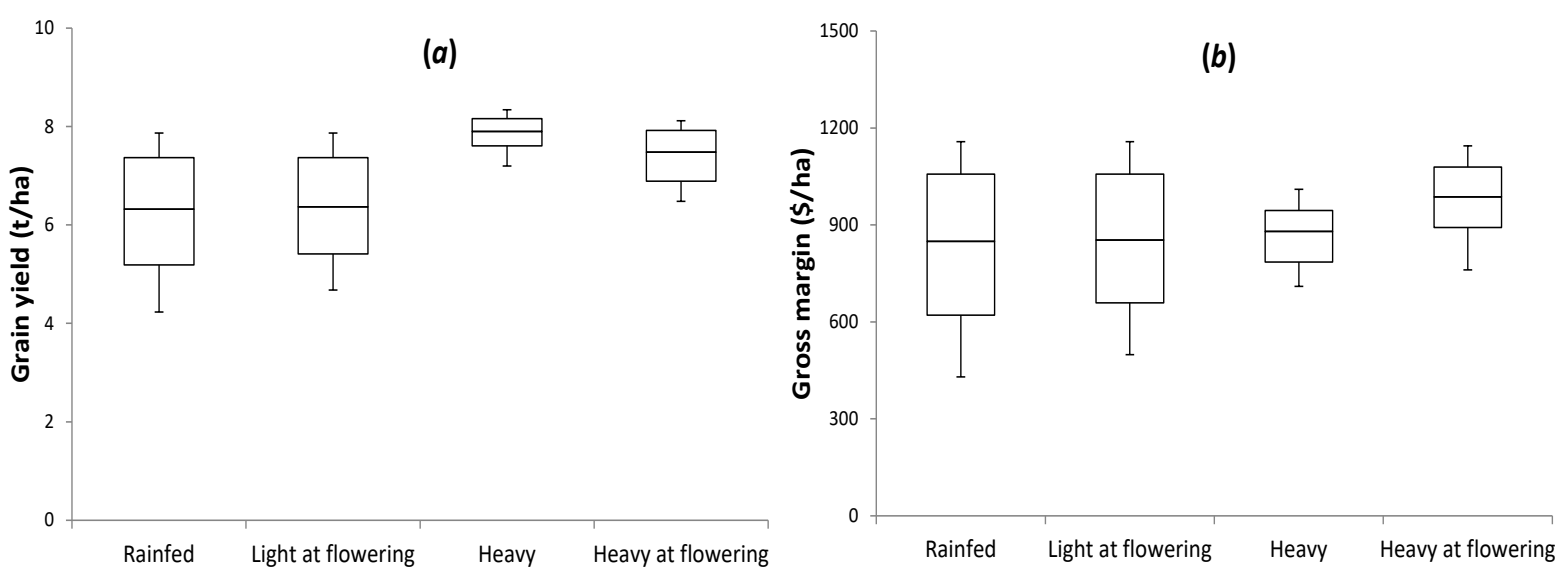
Fig. 11. Simulated wheat grain yield (t/ha) (a) and gross margin (\$/ha) (b) June sowing, Revenue cultivar, Ferrosol soil, rainfed, light irrigation at flowering, heavy irrigation and heavy irrigation at flowering, box plots $\left(5^{\text {th }}, 25^{\text {th }}, 50^{\text {th }}, 75^{\text {th }}\right.$ and $95^{\text {th }}$ percentile $)$ at Sassafras.

The Southern Oscillation Index (SOI, Ropelewski et al., 1987) demonstration (Fig. 12) has been undertaken with the rainfed and heavy irrigation at flowering scenarios as described above. All five phases of the SOI (negative, positive, rapidly falling, rapidly rising and neutral) were selected for two months before sowing (June sowing, SOI phases in April and May), the simulated results for the SOI phases are presented as an impact on the gross margins with each of the phases (Fig. 12). The simulated scenarios indicate that while generally the mean gross margins are similar between rainfed and heavy irrigation at flowering under each SOI phase, the gross margin variability is notably less with the application of irrigation water (except for the negative phase), due to costs associated with irrigation infrastructure and water. In comparing water use with estimated gross margin from CropARM, users can quickly gain an appreciation of which SOI phase will yield the most, and have the greatest grain WUE. Alternatively, users may wish to calculate $\$ /$ ha of grain accounting for the price of water applied.

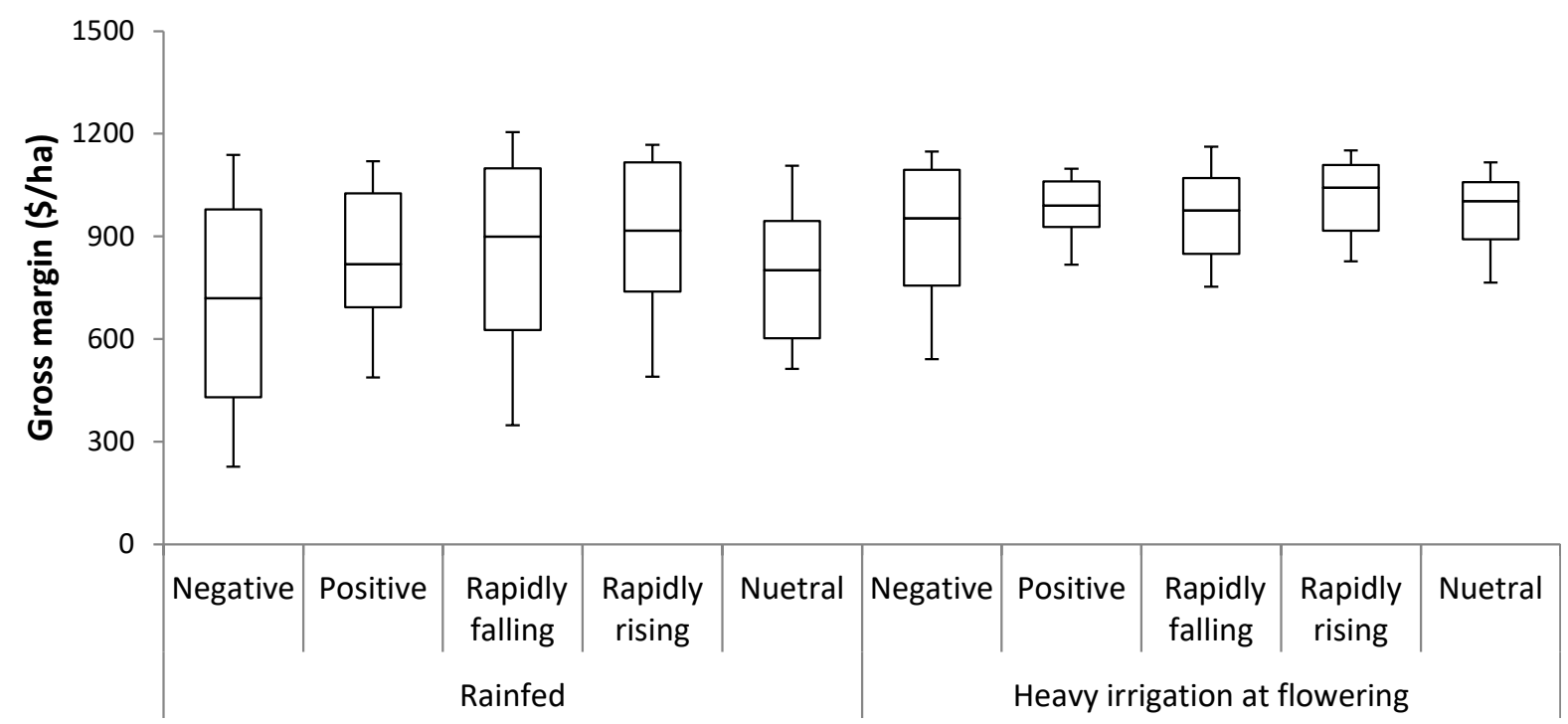

Fig. 12. Simulated gross margin (\$/ha) from the five phases of the SOI during April and May prior to sowing in June for the rainfed and heavy irrigation at flowering scenarios, box plots $\left(5^{\text {th }}, 25^{\text {th }}, 50^{\text {th }}, 75^{\text {th }}\right.$ and $95^{\text {th }}$ percentile) at Sassafras. 


\section{Discussion}

The purpose of this study was firstly to parameterise wheat crop production in APSIM for ten locations

within Tasmania, and secondly to simulate multiple wheat crop production scenarios for each location, and incorporate the parameterised files into CropARM. Prior to this work being undertaken no CropARM data were available for Tasmania. Additionally, no sites currently available in CropARM allowed users to compare rainfed and irrigated crop yields, which will likely form the basis of decisions made by many Tasmanian farmers regarding whether to sow grain crops and/or to apply irrigation water within the growing season. The new CropARM outputs allow users to contrast relative differences in grain yield caused by management decisions, soil type and genotypic differences in multiple regions.

To parameterise APSIM for use in developing simulation scenarios to populate CropARM, we used observed wheat field data from ten sites (Acuna et al., 2015). The model adequately simulated mean annual grain yields attained at the ten sites with an acceptable degree of confidence under rainfed and irrigated conditions. Clearly, there will always be some difference between modelled and measured values, since simulations can differ from actual data due to several reasons (Moellar et al., 2007; Mohanty et al., 2012; Zhao et al., 2014). Variations in results can occur due to factors such as sampling and measurement error, and yields can vary markedly across paddocks due to spatial variability in rainfall, pests and diseases and soil heterogeneity, all of which are not accounted for by the model. Prior parameterisation of APSIM has also shown a general over-prediction in grain yields (Moellar et al., 2007; Mohanty et al., 2012; Zhao et al., 2014; Gaydon et al., 2017), similar to results shown here (Table 4). However, the validity of a biophysical model is not solely reliant on value performance measures, but more so whether the inevitable difference between the simulated and observed values are acceptable (Meinke and Stone, 2005). Gaydon et al., (2017) state that in reality it is unrealistic to expect modelled results to be perfectly the same as the mean of observed values, due primarily to the natural variance measured in observed data, and this is also true when modelling any other biological data. We conclude that the general accuracy and precision of the APSIM model simulations fell within acceptable ranges while factoring in the natural variability of observed field data (Asseng et al., 1998; Pembleton et al., 
2013; Ahmed et al., 2016; Gaydon et al., 2017), demonstrating the ability of the model to simulate mean grain yields at each site, across the various soil types and climatic environments.

Agricultural decision support tools equip users with a rapid and cost effective means of contrasting multiple scenarios to gauge the influence of different management strategies, on farm production and profitability (Nelson et al., 2002; Hochman and Carberry, 2011; Taechatanasat and Armstrong, 2014). Decision support tools also provide means of improving methods with which producers manage their enterprises (Hayman, 2004). CropARM was designed to provide producers, crop management advisers, and other users with access to the latest technology in cropping systems modelling and seasonal climate forecasting (Nelson et al., 2002; Pembleton and Cox, 2017). The climate across south-eastern Australia is highly variable and grain producers are required to make critical management decisions prior to, and during the cropping season. CropARM assists in allowing the exploration of empirical based simulation scenarios which can be used to support risk management in cropping systems via time series, probability, and diagnostic analyses. CropARM enables producers and advisors to compare and contrast different management options, either individually, or in combination.

The advantages CropARM has over similar model-based DS tools such as Yield Prophet is that it is freely available online, the climate data is also regularly updated, and CropARM has a wide range of outputs for users to analyse and explore the potential range of results for the forthcoming season. Similar to CropARM, Yield Prophet (Hochman et al., 2009) acts as an interface to APSIM incorporating soil test results, growing season rainfall, crop management and historic climate data to provide accurate assessments of seasonal yield potential. Yield Prophet Lite (freely available online) was launched to give new users unfamiliar with digital agriculture tools the ability to trial benefits of the DS tool. Yield Prophet Lite contains a simplified feature set allowing farmers to predict the probability of yields for a variety of common crops. In contrast to Yield prophet Lite, Yield Prophet requires a subscription fee and greater user input (e.g. soil test results, accurate growing seasonal rainfall) to ensure reliable seasonal yield potential. CropARM differs from yield Prophet and Yield Prophet Lite in providing results over the long-term (115 year median and ranges), whereas the other DS tools only provide 
estimates of the behaviour of the crop in the current growing season. CropARM also allows users more access to compare alternative management scenarios prior to sowing, but is not specific to a given farm in the way that Yield Prophet and Yield Prophet Lite are. CropARM also calculates over 20 different outputs, including yield, biomass at flowering and harvest, water-use efficiency, the range of potential rainfall received from planting to critical crop stages such as flowering, days to flowering, leaf area index, and effect of temperatures at critical stages.

The examples of CropARM outputs presented in this study clearly demonstrate the advantages of the DS tool for growers, consultants and other agricultural specialists by providing insights into the effects of variable input options. For example, users wanting an estimate of different sowing dates, cultivar selection, and applied $\mathrm{N}$ at Campbell Town can determine that the timing of sowing is having a significant effect on grain yield. It was shown that under rainfed conditions, earlier sowing in either April or May resulted in greater grain yields in contrast to sowing in June or July. These results reiterate an important aspect of sowing time in winter cereals in determining the critical phase of crop development and the environmental conditions under which the crop grows during this period (Acuna et al., 2011; Lou et al., 2011). Sowing later increases the likelihood that high temperatures can induce heat stress around anthesis and during grain fill (Acuna et al., 2011) impacting final grain yields (Calderini et al., 1999; Barlow et al., 2015), as was evident at Campbell Town (Fig. 9).

The CropARM scenario outputs presented also provide insights concerning the impacts of variable $\mathrm{N}$ input options. The efficient use of $\mathrm{N}$ is considered crucial to wheat production and quality (Evans et al., 2001; Brill et al., 2012), where within a given season N rates and timing of application are major tactical tools employed for efficient $\mathrm{N}$ management (McDonald, 1992; Fowler, 2003). Applying $\mathrm{N}$ at sowing commonly facilitates greater crop biomass and subsequent grain yield response in comparison to later application, such as at anthesis, which has little influence on grain yield, but can drive a significant response in grain protein (Brill et al., 2012). This is exemplified at Symmons Plains where a user can quickly determine that the application of $100 \mathrm{~kg} N / \mathrm{ha}$ returns higher grain yields and less annual variability in contrast to applying no nitrogen (Fig. 10a). Ideally the crop N supply should be such that 
the mineralisation of soil organic matter and crop residues be synchronised with the crop demand

469 (Angus 2001). If the $\mathrm{N}$ supply for the crop remains relatively constant (as is the case in CropARM after

470 GS46), an increase in yield generally results in a decrease in grain protein content due to the dilution of

471 N by larger biomass production (Angus, 2001; Fowler, 2003). This was evident at Symmons Plains (Fig

$47210 c$ ), where greater grain yields were negatively correlated with grain protein.

473

474 The economic analysis is computed post APSIM modelling and primarily relies on user inputs, where

475 an estimate of the gross returns less the associated variable input costs is demonstrated at Sassafras

476 (Figs. 11 and 12). Economic analyses may be used to apply a 'marginal analysis' which is concerned

477 with how the addition of another unit of the variable input, such as $\mathrm{N}$ or irrigation water, will change the profitability of the business. Although unknown future crop, fertiliser and irrigation water prices can be more relevant to longer-term decision making where the benefits can accrue over many seasons. As part of the economic analysis, users are required to provide information specific to their own circumstances, such as soil fertility (starting soil N), sowing date, cultivar, and available soil moisture at time of sowing. Users can define potential yields estimates using a mass balance approach, where for example with irrigation application rates at Sassafras, this involves projecting the water limited (rainfed) achievable or target yield and estimating irrigation water required to increase the yield and thus gross margin. For Sassafras, a gross margin analysis was undertaken with the rainfed scenario and three irrigation scenarios of light at flowering, heavy at flowering and heavy irrigation. While the simulated grain yields were greater with the heavy irrigation and heavy irrigation at flowering, the gross margin analysis indicated that greater crop margins were achieved with the heavy irrigation at flowering scenario because the additional cost of irrigation water over the growing season negated the additional grain yield. Conversely, irrigating just at flowering indicates the highest cost-use efficiency of irrigation water. It may be somewhat counterintuitive that higher gross margins are achieved with less irrigation at Sassafras (Fig. 11). This illustrates another advantage of CropARM, where producers could rapidly estimate different irrigation levels and gross margins over a typical season at their location. 
Decision support tools such as CropARM encourage producers to be more tactical through improved management decisions by providing insights into the effects of variable input options. Prior to this study, the DS tools only contained data from mainland Australia and excluded Tasmania (the southernmost state of the continent). Further, agronomic information for mainland sites only contains simulations of rainfed crops, whereas the Tasmanian simulations incorporate both rainfed and irrigated wheat. The development of CropARM for Tasmanian grain producers assists in the ability to project the effects of agronomic management on grain yields, including sowing time, soil type, fertiliser rates and cultivar selection with the ability to characterise the influence of irrigation on grain yield and gross margins. The addition of ten sites across Tasmania within CropARM specifically enables local grain producers to manage production and economic risks with greater flexibility structured for their specific circumstances, allowing producers to continually improve their farming systems. The development of CropARM will also assist independent service providers and policy-makers to predict the impact that different management techniques have on crop production.

\section{Conclusions}

This study collated observed field data from ten sites across the Tasmanian commercial wheat production regions over the period of 1983 to 2010. APSIM was parameterised with the field observations for use in scenario development within CropARM. Prior to this work, there was no data available for Tasmanian wheat growers within CropARM or in other DS tools available for the State. We demonstrated reliable initial model parameterisation and validation, with simulated grain yields that were close to observed values from the ten sites in Tasmania. The new CropARM outputs will allow users to contrast relative differences in grain yield caused by management or genotypic differences in multiple regions. The development of CropARM incorporating multiple scenarios enables agronomic scenario analysis for wheat producers across the State. This will allow crop producers and advisors to examine the full range of possible outcomes across 115 years of historic climate data regarding the financial effect of different levels of inputs, such as irrigation and fertiliser, or soil resources such as water and nitrogen. Further, CropARM assists in management decisions and supporting users to make data-based decisions, allowing continual improvement in their farming systems. Future development of 
523 CropARM and other DS tools capable for use in southern Australia will also help raise profitability and

524 efficiency of Tasmanian farming.

525

\section{Acknowledgements}

527 This research was supported under the Tasmanian Governments Water for Profit program.

528

529

530

531

532

533

534

535

536

537

538

539

540

541

542

543

544

545

546

547

548

References

549 
Acuna, T.B., Dean, G., Riffkin, P., 2011. Constraints to achieving high potential yield of wheat in a

551 temperate, high-rainfall environment in south-eastern Australia. Crop and Pasture Science. 62, 125-

552136.

553

554 Acuna, T.B., Lisson, S., Johnson, P., Dean, G., 2015. Yield and water-use efficiency of wheat in a

555

high-rainfall environment. Crop and Pasture Science 66, 419-429.

556

557

Ahmed, M., Akram, M.N., Asim, M., Aslam, M., Hassan, F., Higgins, S., Stockle, C.O., Hoogenboom,

G., 2016. Calibration and validation of APSIM-Wheat and CERES-Wheat for spring wheat under

rainfed conditions: Models evaluation and application. Computers and Electronics in Agriculture 123,

560

384-401.

561

562

Angus, J.F., 2001. Nitrogen supply and demand in Australian agriculture. Australian Journal of

Experimental Agriculture. 41, 277-288.

564

565

566

567

Asseng, S., Keating,B.A., Fillery, I.R.P., Gregory, P.J., Bowden, J.W., Turner, N.C., Palta, J.A., Abrecht, D.G., 1998. Performance of the APSIM-wheat model in Western Australia. Field Crops Research. 57, 163-179.

568

569

Barlow, K.M., Christy, B.P., O’Leary, G.L., Riffkin, P.A., Nuttall, J.G., 2015. Simulating the impact of extreme heat and frost events on wheat crop production: A review. Field Crops Research. 171, 109119.

572

Brill, R., Gardner, M., Fettell, N., Martin, P., Haskins, B., McMullen, G., 2012. Grain protein concentration of several commercial wheat varieties. Capturing Opportunities and Overcoming 
578 Calderini, D. F., Reynolds, M. P., and Slafer, G. A. 1999. Genetic gains in wheat yield and main 579 physiological changes associated with them during the 20th century. In: Wheat: Ecology and 580 Physiology of Yield Determination (eds E.H. Satorre \& G.A. Slafer), pp. 351-377. Food Products Press, 581 New York.

582

Carberry, P.S., Hochman, Z., McCown, R.L., Dalgliesh, N.P., Foale, M.A., Poulton, P.L., Hargreaves, J.N.G., Hargreaves, D.M.G., Cawthray, S., Hillcoat, N., Robertson, M.J., 2002. The FARMSCAPE approach to decision support: farmers', advisors', researchers', monitoring, simulation, communication and performance evaluation. Agricultural Systems. 74, 141-177.

Cullen, B.R., Eckard, R.J., Callow, M.N., Johnson, I.R., Chapman, D.F., Rawnsley, R.P., Garcia, S.C.,

White, T., Snow, V.O., 2008. Simulating pasture growth rates in Australia and New Zealand grazing systems. Australian Journal of Agricultural Research. 59, 761-768.

591

Evans, J., McNeill, A.M., Unkovich, M.J., Fettell, N.A., Heenan, D.P., 2001. Net nitrogen balances for 593 cool-season grain legume crops and contributions to wheat nitrogen uptake: A review. Australian Journal of Experimental Agriculture. 41, 347-359.

595

Fowler, D.B., Brydon, J., Darroch, B.A., Entz, M.H., Johnston, A.M., 1990. Environment and genotype influence on grain protein concentration of wheat and rye. Agronomy Journal. 82, 666-674.

Fowler, D.B., 2003. Crop nitrogen demand and grain protein concentration of spring and winter wheat.

601

Gauer, L.E., Grant, C.A., Gehl, D.T., Bailey, L.D., 1992. Effects of nitrogen fertilization on grain 603 protein content, nitrogen uptake, and nitrogen use efficiency of six spring wheat (Triticum aestivum L.) cultivars, in relation to estimated moisture supply. Canadian Journal of Plant Science. 72, 235-241. 
607 Amarasingha, R., Chaki, A.K., Chen, C., Choudhury, B.U., Darai, R., Das, A., Hochman, Z., Horan, M.A.P.W.K., Mohapatra, K.P., Muttaleb, M.A., Power, B., Radanielson, A.M., Rai, G.S., Rashid, M.H., Rathanayake, W.M.U.K., Sarker, M.M.R., Sena, D.R., Shamim, M., Subash, N., Suriadi, A., model in cropping systems of Asia. Field Crops Research. 204, 52-75.

Grose, M.R., Barnes-Keoghan, I., Corney, S.P., White, C.J., Holz, G.K., Bennett, J.B., Gaynor, S.M., Bindoff, N.L., 2010. Climate Futures for Tasmania general climate impacts technical report. Antarctic

Harrison, M.T., Evans, J.R., Dove, H., Moore, A.D., 2011. Recovery dynamics of rainfed winter wheat after livestock grazing 1. Growth rates, grain yields, soil water use and water-use efficiency. Crop and Pasture Science. 62, 947-959.

621

Hayman, P., 2004. Decision support systems in Australian dryland farming: A promising past, a disappointing present and uncertain future. Proceedings of the 4th International Crop Science Congress, Brisbane, Australia.

Hochman, Z., van Rees, H., Carberry, P.S., Hunt, J.R., McCown, R.L., Gartmann, A., Holzworth, D., van Rees, S., Dalgliesh, N.P., Long, W., Peake, A.S., Poulton, P.L., McClelland, T., 2009. Re-inventing model-based decision support with Australian dryland farmers. 4. Yield Prophet helps farmers monitor and manage crops in a variable climate. Crop and Pasture Science. 60, 1057-1070.

630

Hochman, Z., Carberry, P.S., 2011. Emerging consensus on desirable characteristics of tools to support farmers’ management of climate risk in Australia. Agricultural Systems. 104, 441-450. 
638

639

640

641

642

643

644

645

646

647

648

649

650

651

652

653

654

655

656

657

658

659

660

Holzworth, D., Meinke, H., DeVoil, P., Wegener, P., Huth, N., Hammer, G., Howden, M., Robertson, M., Carberry, M., Freebairn, D., Murphy, C., 2006. The development of a farming systems model (APSIM) - a disciplined approach. International Congress on Environmental Modelling and Software. http://www.iemss.org/iemss2006/papers/w4/Holzworth.pdf

Hunt, J., van Rees, H., Hochman, Z., Carberry, P., Holzworth, D., Dalgliesh, N., Brennan, L., Poulton, P., van Rees, S., Huth, N., Peake, A., 2006. Yield Prophet: An online crop simulation service. Proceedings of the 13th ASA Conference, 10-14 September 2006, Perth, Western Australia. https://www.researchgate.net/publication/228683328_Yield_ProphetR_An_online_crop_simulation_s ervice

Jakku, E., Thorburn, P.J., 2010. A conceptual framework for guiding the participatory development of agricultural decision support systems. Agricultural Systems. 103, 675-682.

Jeffrey, S.J., Carter, J.O., Moodie, K.M., Beswick, A.R., 2001. Using spatial software to construct a comprehensive archive of Australian climate data. Environmental Modelling and Software. 16, 309330.

Keating, B.A., Carberry, P.S., Hammer, G.L., Probert, M.E., Robertson, M.J., Holzworth, D., Huth, N.I., Hargreaves, J.N.G., Meinke, H., Hochman, Z., McLean, G., Verbug, K., Snow, V., Dimes, J.P., Silburn, M., Wang, E., Brown, S., Bristow, K.L., Asseng, S., Chapman, S., McCown, R.L., Freebairn, D.M., Smith, C.J., 2003. An overview of APSIM, a model designed for farming systems simulation. European Journal of Agronomy. 18, 267-288.

Lisson, S.N., Cotching, W.E., 2011. Modelling the fate of water and nitrogen in the mixed vegetable farming systems of northern Tasmania, Australia. Agricultural Systems. 104, 600-608. 
661 Lou, Z., Wang, E., Sun, O.J., Smith, C.J., Probert, M.E., 2011. Modelling long-term soil carbon

662 dynamics and sequestration potential in semi-arid agro-ecosystems. Agricultural and Forestry

663 Meteorology. 151, 1529-1544.

664

665 McCormick, J.L., Virgona, J.M., Lilley, J.M., Kirkegaard, J.A., 2015. Evaluating the feasibility of dual666 purpose canola in a medium-rainfall zone of south-eastern Australia: a simulation approach. Crop \& 667 Pasture Science 66, 318-331.

668

McDonald, G.K., 1992. Effects of nitrogenous fertilizer on the growth, grain yield and grain protein concentration of wheat. Crop and Pasture Science. 43, 949-967.

671

672

Meinke, H., Stone, R., 2005. Seasonal and inter-annual climate forecasting: the new tool for increasing preparedness to climate variability and change in agricultural planning and operations. Climatic Change. 70, 221-253.

675

Moeller, C., Pala, M., Manschadi, A.H., Meinke, H., Sauerborn, J., 2007. Assesing the sustainability of wheat-based cropping systems using APSIM: model parameterisation and evaluation. Australian Journal of Agricultural Research. 58, 75-86.

679

Mohanty, M., Probert, M.E., Reddy, K.S., Dalal, R.C., Mishra, A.K., Rao, A.S., Singh, M., Menzies, N.W., 2012. Simulating soybean-wheat cropping system: APSIM model parameterization and validation. Agriculture, Ecosystems and Environment. 152, 68-78.

683

684

Nelson, R.A., Holzworth, D.P., Hammer, G.L., Hayman, P.T., 2002. Infusing the use of seasonal 685 climate forecasting into crop management practice in North East Australia using discussion support software. Agricultural Systems. 74, 393-414. 
Nguyen, N.C., Wegner, M., Russell, I., 2007. Decision support systems in Australian agriculture: state of the art and future development. ABFM Journal. 4, 14-21.

690

691

Oweis, T., Pala, M., Ryan, J., 1998. Stabilizing rainfed wheat yields with supplement irrigation and 692 nitrogen in a Mediterranean climate. Agronomy Journal. 90, 672-681.

693

694

Pembleton, K.G., Rawnsley, R.P., Jacobs, J.L., Mickan, F.J., O’Brien, G.N., Cullen, B.R., Ramilan, T., 2013. Evaluating the accuracy of the Agricultural Production Systems Simulator (APSIM) simulating growth, development, and herbage nutritive characteristics of forage crops grown in south-eastern dairy regions of Australia. Crop and Pasture Science. 64, 147-164.

698

Pembleton, K.G., Cox, H., 2017. University of Southern Queensland, Department of Agriculture and Fisheries, Queensland. https://grdc.com.au/resources-and-publications/grdc-updatepapers/tab-content/grdc-update-papers/2017/07/new-tools-to-help-grain-growers-understandand-manage-risks-with-fallowarm-sand-croparm

703

Ryan, J., 2015. http://www.abc.net.au/news/2015-08-30/plans-to-double-tasmania-grain705 production-to-match-dairy/6734150

706

707

Robertson, M.J., Lilley, J.M., 2016. Simulation of growth, development and yield of canola (Brassica napus) in APSIM. Crop and Pasture Science. 67, 332-344.

709

Ropelewski, C.F., Jones, P.D., 1987. An extension of the Tahiti-Darwin Southern Oscillation Index. Monthly Weather Review. 115, 2161-2165.

712

Rose, D.C., Sutherland, W.J., Parker, C., Lobley, M., Winter, M., Morris, C., Twining, S.,

714 Ffoulkes, C., Amano, T., Dicks, L.V., 2016. Decision support tools for agriculture: Towards 715 effective design and delivery. Agricultural Systems. 149, 165-174. 
717 Taechatanasat, P., Armstrong, L., 2014. Decision support system data for farmer decision making.

718 Proceedings of AFITA. http://asicta.org/AFITA2014/

719

720 Tedeschi, L.O., 2006. Assessment of the adequacy of mathematical models. Agricultural Systems 721 89, 225-247.

722

723 Wang, J., Wang, E., Liu, D.L., 2010. Modelling the impacts of climate change on wheat yield and 724 field water balance over the Murray-Darling Basin in Australia. Theoretically Applied 725 Climatology. 104, 285-300.

726

727 Zadoks, J.C., Chang, T.T., Konzak, C.F., 1974. Decimal code for growth stages of cereals. Weed 728 Research. 14, 415-421.

729

730 Zhao, G., Bryan, B.A., Song, X., 2014. Sensitivity and uncertainty analysis of the APSIM-wheat 731 model: Interactions between cultivar, environment and management parameters. 279, 1-11. 